\section{I samsvar med lova}

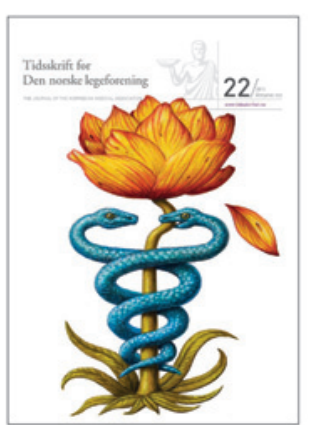

I september 2013 vedtok Det medisinske fakultet i Oslo ein ny, revidert studieplan for medisinstudiet, og fakultetsstyret vedtok med sju mot to stemmer at karaktersystemet for det reviderte studiet skal ha graderte karakterar, med høve til å bruke bestått/ikkje bestått i enkelte emne (1). I artikkelen Skittent spill rundt innføring av karakterer i Tidsskriftet nr. 22/2013 kjem medisinstudent Christoffer Smith med ei rekkje påstandar om prosessen fram til vedtaket (2). Han hevdar mellom anna at Det medisinske fakultet har brote $\S 4-4$ i universitets- og høgskulelova om studentrepresentasjon, noko som ikkje er korrekt ifølgje juridisk ekspertise ved vårt universitet.

Reglane i lova gjeld vedtaksorgan. Realiteten er at fakultetsstyret som er fakultetet sitt øvste vedtaksorgan, har ein studentrepresentasjon på over $20 \%$ (to av ni medlemar er studentar). Fakultetsstyret oppnemnde ei styringsgruppe for revisjonsprosjektet, og i denne gruppa har studentrepresentasjonen vore på $20 \%$ (ein av fem medlemar). Då gruppa blei utvida, blei det oppnemnd ein ekstra student, slik at studentrepresentasjonen blei $25 \%$.

I ein tidleg fase av arbeidet med revisjonen blei det valgt ei arbeidsgruppe, og det blei sidan sett ned ei prosjektgruppe. Desse gruppene har ikkje hatt status som vedtaksorgan, men hadde i oppdrag å greie ut og kome med forslag til løysingar. Då gruppene blei danna, la ein vekt på å sikre brei representasjon frå lærarstaben. Involvering og dialog med studentane har vi søkt å vareta på ei rekkje måtar i dette arbeidet. Eg er derfor heilt trygg på at vi i denne prosessen har gått fram på ein måte som har vore fullt ut i samsvar med lova og god forvaltningsskikk.

\section{Frode Vartdal}

frode.vartdal@medisin.uio.no

Frode Vartdal (f. 1949) er dekan ved Det medisinske fakultet, Universitetet i Oslo, frå januar 2011 og er professor i immunologi frå 1990.

Ingen oppgjevne interessekonfliktar.

\section{Litteratur}

1. Oslo 2014 - revisjon av profesjonsstudiet i medisin: www.med.uio.no/om/ prosjekter/oslo-2014/ (28.10.2013)

2. Smith C. Skittent spill rundt innføring av karakterer. Tidsskr Nor Legeforen 2013; 133: 2340-1

Dette er en redigert versjon av debatten, publisert på nett 28.10.2013. http://tidsskriftet.no/article/3104192/

\section{Prosess med stort engasjement}

I artikkelen Skittent spill rundt innføring av karakterer i Tidsskriftet nr. 22/2013 (1), kritiserer medisinstudent Christoffer Smith prosessen frem til vedtaket om å innføre graderte karakterer i det reviderte medisinstudiet i Oslo (2).

Han hevder bl.a. at Det medisinske fakultet har brutt universitetsog høyskoleloven, noe jeg mener han tar feil i. Jeg synes det er nødvendig å korrigere bildet Smith tegner av prosessen. Jeg var prosjektleder i perioden fra januar og frem til august 2013 og ledet en prosjektgruppe som var oppnevnt av styringsgruppen for prosjektet, og spørsmålet om karaktersystem var ett av flere viktige områder vi arbeidet med.

I løpet av 2013 arrangerte prosjektgruppen ni allmøter om revisjonen, og studenter deltok og formidlet sine synspunkter på flere av disse møtene. Prosjektgruppen arrangerte i april 2013 et dagsseminar med over 100 deltakere, inkludert fakultets ledelse, hvor studentrepresentanter fra alle kull var invitert. En studentrepresentant fikk $i$ en egen programpost legge frem studentenes perspektiv, og studentenes syn på karaktersystemet ble gjort rede for. Min opplevelse er at begge studentene i prosjektgruppen var aktive og effektive formidlere av studentenes interesser og synspunkter gjennom hele prosessen.

Jeg hadde som prosjektleder møter med representanter fra Medisinsk fagutvalg, det demokratisk valgte organet for medisinstudentene i Oslo, i januar og i mai 2013. Vi fikk en rekke innspill på e-post, og jeg har lyttet til og hatt møter med alle studenter som har hatt ønske om å formidle sine synspunkter.

Helt fra starten av prosessen har jeg opplevd et stort og positivt engasjement rundt revisjonen av studiet, og særlig når det gjaldt spørsmålet om karaktersystem. Det har hele tiden vært full åpenhet om at det rådet ulike syn om graderte karakterer. Prosjektgruppen valgte å formulere fire ulike løsningsforslag som vi mente dekket bredden i synspunktene som var fremkommet i dialogen med ansatte og studenter (3). Fordeler og ulemper ble belyst, og i tråd med vanlig praksis innen offentlig utredning valgte vi å synliggjøre uenigheten i prosjektgruppen overfor beslutningsorganet. Et flertall og et mindretall ga sin tilrådning om to ulike løsninger på spørsmålet om karaktersystem (3). Studentene har vært involvert og har hatt innflytelse på utformingen av løsningsforslagene, og deres synspunkter og argumenter er hørt. Det er et bare å konstatere at det i denne saken forelå en reell studiepolitisk uenighet, og at et flertall i fakultetsstyret vedtok et annet alternativ enn hva mange studenter ønsket.

\section{Jan Frich}

jan.frich@medisin.uio.no

Jan Frich (f. 1970) var prosjektleder for revisjonen av medisinstudiet ved Det medisinske fakultet, Universitetet i Oslo, fra januar og frem til august 2013, og er i studieåret 2013/14 Harkness fellow og gjesteprofessor ved Yale University.

Ingen oppgitte interessekonflikter.

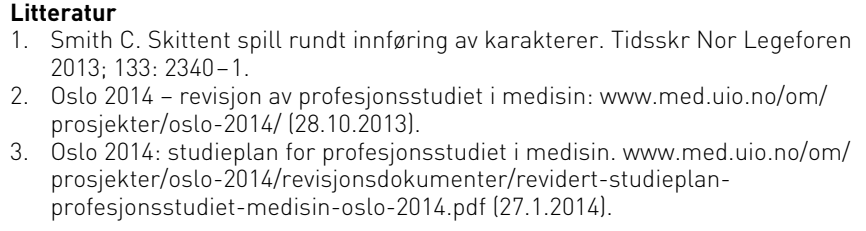

Dette er en redigert versjon av debatten, publisert først på nett 29.10.2013. http://tidsskriftet.no/article/3104192/

\section{Behov for å endre sannheten?}

Frode Vartdal og Jan Frich forsøker å svare på noe av kritikken jeg presenterer i min kommentar i Tidsskriftet. Jeg merker meg at Vartdal kun kommenterer spørsmålet om lovbrudd, og lar kritikken om ledelsens holdninger til studenter være ubesvart. Dessverre har selvkritikk lenge vært sjelden vare fra ledelsen ved Det medisinske fakultet.

Det er et juridisk vurderingsspørsmål hvorvidt arbeids-, prosjektog styringsgruppene for revisjonen har hatt beslutningsmyndighet eller ikke - og om fakultetet dermed har brutt loven på grunn av for liten studentrepresentasjon. Uavhengige juridiske eksperter på forvaltningsrett, også i departementene, har arbeidet med saken på studentenes vegne og mener, i motsetning til universitetets egne jurister, at det har forekommet lovbrudd.

Vartdal nevner selv styringsgruppen som et organ med beslutningsmyndighet og tilstrekkelig studentrepresentasjon. Ifølge møtereferater har det vært avholdt fire møter i styringsgruppen (1). Første møte fant sted i januar 2013, og gruppen besto av fem personer, derav kun én student. I mars 2013 ble gruppen utvidet med ytterligere to representanter fra universitetssykehusene. Under de to neste møtene, begge i mai 2013, var derfor kun ett av sju medlemmer student. Først i det fjerde møtet i august 2013 utnevnte man en ekstra studentrepresentant. Det tok altså ledelsen mer enn fem måneder 